\title{
Climate and season are associated with prevalence and distribution of trans-hemispheric blue crab reovirus (Callinectes sapidus reovirus 1)
}

\author{
Mingli Zhao' ${ }^{1}$, Donald C. Behringer ${ }^{2,3}$, Jamie Bojko ${ }^{4}$, Andrew S. Kough5 ${ }^{5}$ Louis Plough ${ }^{6}$, \\ Camila Prestes dos Santos Tavares ${ }^{7}$, Alfonso Aguilar-Perera ${ }^{8}$, Omar Shamir Reynoso ${ }^{9}$, \\ Govind Seepersad ${ }^{10}$, Omardath Maharaj ${ }^{10}$, Matthew B. Sanders ${ }^{11}$, Daniela Carnales ${ }^{12}$, \\ Graciela Fabiano ${ }^{12,13}$, Daniel Carnevia ${ }^{12}$, Mark A. Freeman ${ }^{14}$, Nicole A. M. Atherley ${ }^{14,15}$, \\ Lexa D. Medero-Hernández ${ }^{16,18}$, Eric J. Schott ${ }^{17, *}$
}

\footnotetext{
${ }^{1}$ Institute of Marine and Environmental Technology, University of Maryland, Baltimore County, Baltimore, MD 21202, USA

${ }^{2}$ University of Florida, Fisheries and Aquatic Sciences, Gainesville, FL 32653, USA

${ }^{3}$ University of Florida, Emerging Pathogens Institute, Gainesville, FL 32608, USA

${ }^{4}$ Teesside University, School of Health and Life Sciences, Middlesbrough TS1 3BA, UK

${ }^{5}$ John G. Shedd Aquarium, Haerther Center for Conservation Research, Chicago, IL 60605, USA

${ }^{6}$ University of Maryland Center for Environmental Science, Cambridge, MD 21613, USA

${ }^{7}$ Integrated Group of Aquaculture and Environmental Studies, Federal University of Paraná, Rua dos Funcionários 1540, Curitiba, PR 80035-050, Brazil

${ }^{8}$ Departamento de Biología Marina, Universidad Autónoma de Yucatán, Mérida, Yucatán, Mexico

${ }^{9}$ National Authority for Maritime Affairs, Santo Domingo, Dominican Republic

${ }^{10}$ Department of Agricultural Economics and Extension, University of the West Indies, St Augustine Campus, Trinidad, West Indies

${ }^{11}$ Centre for Environment, Fisheries and Aquaculture Science, Weymouth, Dorset DT4 8UB, UK

${ }^{12}$ Veterinary Faculty, Fisheries Research Institute, Tomas Basañez 1160, Uruguay

${ }^{13}$ National Directorate of Aquatic Resources, Atlantic Fisheries Management Unit, La Paloma, Rocha, Uruguay

${ }^{14}$ Ross University School of Veterinary Medicine, Basseterre, Saint Kitts, West Indies

${ }^{15}$ Caribaea Initiative, Université des Antilles, Pointe-á-Pitre, Guadeloupe

${ }^{16}$ Universidad Ana G. Méndez, Recinto de Cupey, San Juan, PR 00926, USA

${ }^{17}$ Institute of Marine and Environmental Technology, University of Maryland Center for Environmental Science, Baltimore, MD 21202, USA

${ }^{18}$ Present address: Florida Agricultural \& Mechanical University, Tallahassee, FL 32307, USA
}

\begin{abstract}
Among the many Callinectes spp. across the western Atlantic, the blue crab C. sapidus has the broadest latitudinal distribution, encompassing both tropical and temperate climates. Its life history varies latitudinally, from extended overwintering at high latitudes to year-round activity in tropical locations. Callinectes sapidus reovirus 1 (CsRV1) is a pathogenic virus first described in North Atlantic C. sapidus and has recently been detected in southern Brazil. Little information exists about CsRV1 prevalence at intervening latitudes or in overwintering blue crabs. Using a quantitative reverse transcription PCR (RT-qPCR) method, this study investigated CsRV1 prevalence in C. sapidus across latitudinal differences in temperature and crab life history, as well as in additional Callinectes spp. and within overwintering C. sapidus. CsRV1 prevalence in $C$. sapidus was significantly correlated with high water temperature and blue crab winter dormancy. Prevalence of CsRV1 in C. sapidus on the mid-Atlantic coast was significantly lower in winter than in summer. CsRV1 infections were not detected in other Callinectes spp. These findings revealed that CsRV1 is present in C. sapidus across their range, but not in other Callinectes species, with prevalence associated with temperature and host life history. Such information helps us to better understand the underlying mechanisms that drive marine virus dynamics under changing environmental conditions.
\end{abstract}

KEY WORDS: CsRV1 - Disease ecology - Dormancy - Latitudinal gradient - Life history · Population density $\cdot$ Temperature

${ }^{*}$ Corresponding author: schott@umces.edu
(1) The authors 2020. Open Access under Creative Commons by Attribution Licence. Use, distribution and reproduction are unrestricted. Authors and original publication must be credited. 


\section{INTRODUCTION}

Since the last glacial maximum, the distribution of crabs in the genus Callinectes has radiated poleward from a center in the Atlantic coastal region (Williams 1974). Within the genus, the blue crab C. sapidus has the broadest latitudinal distribution, along the Atlantic coast from Nova Scotia, Canada, to as far south as northern Argentina, with variable abundance in different regions (Williams 1974). Throughout its range, C. sapidus functions as both predator and prey in estuarine food webs and supports important commercial and recreational fisheries that employ thousands of harvesters and have landings worth \$200 million annually (Arnold 1984, Lipcius 1986, Hines 2003, National Marine Fisheries Service 2020).

The life history of $C$. sapidus varies latitudinally because its growth, maturation, and behavior are temperature-dependent. The minimum water temperature for activity in blue crabs is approximately $10^{\circ} \mathrm{C}$, below which they reduce their metabolic rate and enter dormancy (Brylawski \& Miller 2006, Hines 2007). In the mid-latitudes of the northern Atlantic, where water temperatures dip below $10^{\circ} \mathrm{C}$ in winter, blue crabs migrate into deep waters or burrow into estuarine sediments to overwinter, displaying little activity (Hines et al. 2011). In warmer waters, such as the southern US Atlantic, Gulf of Mexico, and Caribbean Sea, C. sapidus have an extended spawning period, year-round recruitment, and are continuously active (Adkins 1972, Hsueh et al. 1993). In the higher latitudes of Brazil and south to Argentina, blue crab activity again becomes seasonal as winter water temperatures approach $10^{\circ} \mathrm{C}$ (Rodrigues et al. 2019).

Throughout their range, blue crabs are host to viral, bacterial, fungal, protozoan, and metazoan pathogens (Messick 1998, Small et al. 2019, Messick \& Shields 2000). Various viruses have been described, with the most studied being Callinectes sapidus reovirus 1 (CsRV1). It was identified as a cause of mortality in captive blue crabs, particularly in soft crab aquaculture (Johnson 1977, Bowers et al. 2010, Spitznagel et al. 2019), and in the laboratory, individuals experimentally infected with CsRV1 suffered $100 \%$ mortality within 16 d (Bowers et al. 2010). The virus infects hemocytes, gills, nervous system, and connective tissue, which in turn invades the brain and thoracic globules and is associated with tremors and paralysis (Johnson 1977). CsRV1 has been previously identified in wild blue crabs from the US Atlantic and Gulf coasts and from southern Brazil (Bowers et al. 2010, Flowers et al. 2016a,b). The prevalence of CsRV1 has been found to be spatially and temporally variable along the northern Atlantic coast of the USA (Flowers et al. 2016a,b). The transmission mechanism of CsRV1 remains uncertain, but could include ingestion, cannibalism, or waterborne transport (Johnson 1977).

The prevalence of viral pathogens in aquatic environments varies geographically as a result of the interplay between pathogen, host, and the environment (Engering et al. 2013). The pathogenicity and transmissibility of viruses can be affected by both extrinsic and intrinsic factors. Extrinsic factors include climatic changes, temperature, salinity and host density, while intrinsic factors include viral virulence, host life history, behavior, and immune response (Hardy et al. 1983, Samuel et al. 2016, Behringer et al. 2018). Temperature is particularly important for the distribution of most viral pathogens (Ford \& Chintala 2006, Hawley \& Garver 2008, Goodwin \& Merry 2011, Samuel et al. 2016), and susceptibility to infections is expected to vary with temperature due to alterations of the host's metabolic rate, immune response, and behavioral adaptations (Brady et al. 2014, Hoberg \& Brooks 2015, Franke et al. 2017, Labaude et al. 2017, Behringer et al. 2018). For example, CsRV1-infected blue crabs have upregulated immune gene expression in water temperatures exceeding $23^{\circ} \mathrm{C}$ (Chung et al. 2015). Behavioral adaptations of the blue crab include overwintering dormancy, peaks in mating and reproduction, and associated migrations.

The blue crab has a plastic life history (winter dormancy or active year-round) depending on its climate (temperate or tropical), providing an opportunity to investigate the effect of life history on infection dynamics and disease ecology. The prevalence of CsRV1 during summer has been reported from the US Atlantic and Gulf coasts (Bowers et al. 2010, Rogers et al. 2015b, Flowers et al. 2016b), but there has been no modern investigation using molecular detection methods of CsRV1 prevalence in lower latitudes or in winter-dormant blue crabs. The aim of this study was to measure CsRV1 prevalence in C. sapidus and other Callinectes spp. along a latitudinal distribution from the US Atlantic coast, Gulf of Mexico, Caribbean Sea, and Atlantic coast of South America. The data were analyzed to explore how different annual temperature and dormancy regimes, which drive host life history patterns, may also drive patterns of CsRV1 infection in blue crabs across space and time. 


\section{MATERIALS AND METHODS}

\subsection{Crab sampling and environmental data}

A total of 1510 Callinectes sapidus and 577 additional Callinectes spp. were collected from 22 locations along the western Atlantic coasts ranging from Massachusetts (USA) to Uruguay between 2015 and 2019 (Fig. 1, see Table 1). Collection methods included baited traps, trawls, seines, and gillnets. Crab sex, carapace width (CW; measured lateral spine-tospine), sample date, and location were recorded for specimens when possible (exceptions: Long Island [NY], Dominican Republic, and Rio Grande do Sul). Two walking legs were removed from each crab for further analysis. Leg samples collected from Massachusetts, New York, and Delaware were placed on ice for overnight shipping, while samples from more distant locations (including those in Florida, Texas, Mexico, Dominican Republic, Puerto Rico, St Kitts \& Nevis, St Lucia, Trinidad \& Tobago, Paraná, Sergipe and Rio Grande do Sul of Brazil, and Uruguay) were preserved in $95 \%$ ethanol or $>120$ proof white rum for shipping to the Institute of Marine and Environ-

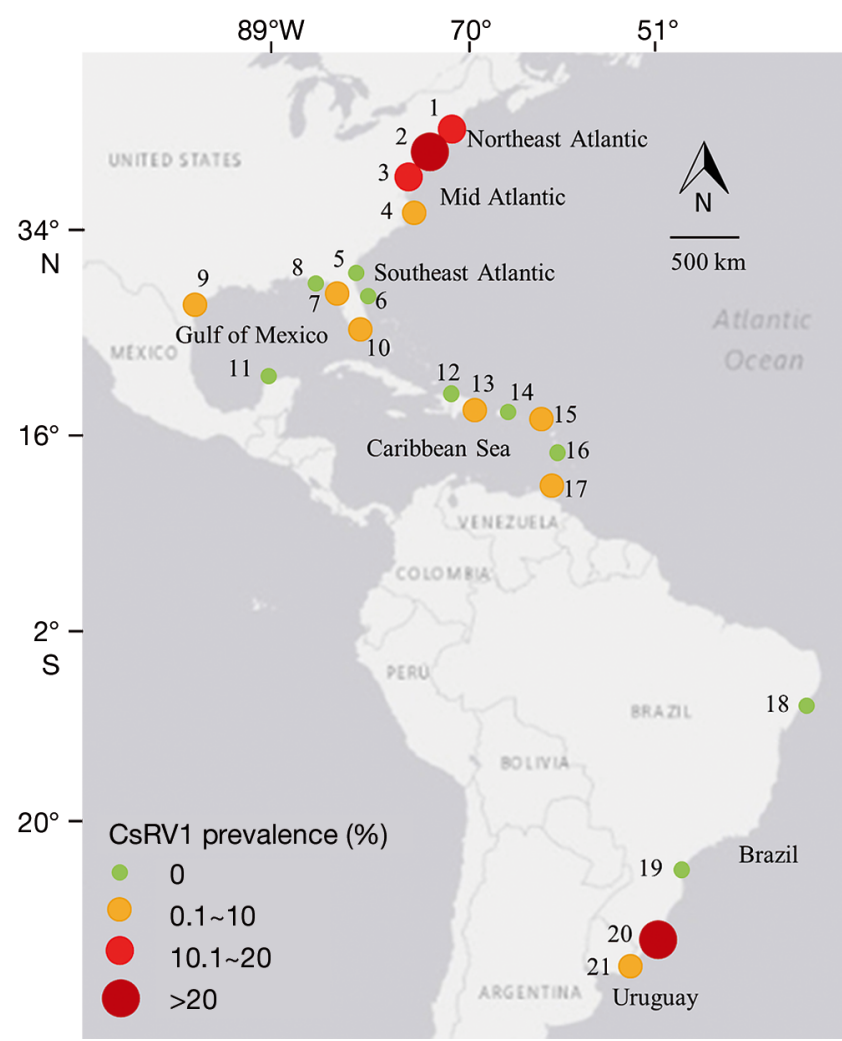

Fig. 1. Prevalence of Callinectes sapidus reovirus 1 (CsRV1) in $C$. sapidus along the western Atlantic coast. The color and size of each circle indicates CsRV1 prevalence. Numbers refer to Map ID; see Table 1 for location names mental Technology (IMET). At IMET, the samples were stored at $-20^{\circ} \mathrm{C}$ until analysis. Taxonomic identifications based on their physical characteristics confirmed most specimens as C. sapidus, but other Callinectes spp. were also identified (Melo 1996, Williams 2007). Identification of some species was further confirmed by sequence analysis of the cytochrome $c$ oxidase subunit I ( $\operatorname{cox} 1$ ) or $12 \mathrm{~S}$ gene (Leray \& Knowlton 2015, L. Plough et al. unpubl. data).

Water temperature data were obtained from nearby NOAA buoys and downloaded from the National Buoy Data Center (www.ndbc.noaa.gov) for US and Caribbean regions, and obtained from Hidrografia da Marinha (https://www.marinha.mil.br/chm/dadosdo-goos-brasil/pnboia-mapa) for Brazilian locations. According to the reported threshold for C. sapidus activity and susceptibility to CsRV1, the number of days with water temperature below $10^{\circ} \mathrm{C}\left(D_{<10}\right)$ and above $23^{\circ} \mathrm{C}\left(D_{>23}\right)$, were calculated based on the recorded historical water temperature data of the nearby buoys (Table S1 in the Supplement at www.int-res.com/articles/suppl/m647p123_supp.pdf). In Uruguay, water temperature was based on published studies (Guerrero et al. 1997, 2010).

A total of 469 winter-dormant $C$. sapidus were collected from the Upper Chesapeake Bay, Potomac River (Maryland, USA), Lower Chesapeake Bay (Virginia, USA), Delaware Bay (Delaware, USA), and Albemarle Sound (North Carolina, USA), during the winters of 2015, 2018, and 2019. Frozen crab legs or live crabs (at $0-4^{\circ} \mathrm{C}$ ) were transported to IMET and were either stored at $-20^{\circ} \mathrm{C}$ for later analysis or measured and dissected immediately. For the months of sampling, maximum and minimum temperatures for sampling locations were obtained from nearby NOAA buoys from the National Buoy Data Center (Table S2).

\subsection{Dissection and RNA extraction}

Crab dissections were conducted as described by Flowers et al. (2016b), with modification. Bench surfaces for dissection and crabs were cleaned with ELIMINase $^{\mathrm{TM}}$ and dissections were performed using sterile wooden rods and single-use razor blades. Approximately $50 \mathrm{mg}$ of muscle and epidermis tissue were dissected from a walking leg and homogenized using a Savant $\mathrm{MP}^{\circledR}$ FastPrep24 homogenizer with ceramic beads in $1.0 \mathrm{ml}$ TRIzol (VWR Scientific) or homemade Trizol substitute (Rodríguez-Ezpeleta et al. 2009). RNA extraction followed the protocol used by Spitznagel et al. (2019). RNA pellets were dis- 
solved in $50 \mu \mathrm{l} 1 \mathrm{mM}$ EDTA and stored at $-80^{\circ} \mathrm{C}$. Negative control samples (muscle from frozen smelt) were extracted before and after sets of tested crab samples to monitor for cross contamination between samples. RNA purity and concentration were determined by NanoDrop ${ }^{\mathrm{TM}}$ spectrophotometry, and electrophoretic gel of some specimens was analyzed to verify RNA quality.

\subsection{Quantitative reverse transcription PCR of CsRV1}

CsRV1 infection was assessed by measuring the relative copy number of CsRV1 genomes (subject to RNA background) present in crab tissue using the quantitative reverse transcription PCR (RT-qPCR) methods adapted from Flowers et al. (2016b), with a primer pair designed to detect a 158-bp region of the ninth genome segment of CsRV1 (GenBank entry KU311716): 5' -TGC GTT GGA TGC GAA GTG ACA AAG-3' (RLVset1F) and 5'-GCG CCA TAC CGA GCA AGT TCA AAT-3' (RLVset1R). Standard curves were generated by RT-qPCR amplifications of a 10-fold dilution series of purified double-stranded RNA (dsRNA) from CsRV1 containing $10-10^{6}$ CsRV1 genome copies $\mu^{-1}$. Viral dsRNA was purified using CF11 cellulose affinity chromatography (Flowers et al. 2016b) from crabs heavily infected with CsRV1 $\left(>10^{8}\right.$ copies $\mathrm{mg}^{-1}$ muscle), and then quantified and serially diluted in $25 \mathrm{ng} \mathrm{\mu l}^{-1}$ yeast tRNA carrier. The qPCR cycling conditions and reagents were as described by Spitznagel et al. (2019), using qScript ${ }^{\mathrm{TM}}$ One-Step qRT-PCR Kit (Quanta Bio) in $10 \mu \mathrm{l}$ reactions containing $0.5 \mu \mathrm{M}$ of each primer. To anneal PCR primers to dsRNA, primers and extracted RNA were combined, heated to $95^{\circ} \mathrm{C}$ for 5 min then cooled to $4^{\circ} \mathrm{C}$ prior to being added to the reverse transcriptase and Taq polymerase reaction mixture. Reverse transcription and amplification conditions were as follows: $50^{\circ} \mathrm{C}$ for $5 \mathrm{~min}$ (reverse transcription) followed by $5 \mathrm{~min}$ at $95^{\circ} \mathrm{C}$ (reverse transcriptase inactivation and template denaturation). Amplification was achieved through 40 cycles of $95^{\circ} \mathrm{C}$ for $5 \mathrm{~s}$ (denaturation), and $61^{\circ} \mathrm{C}$ for $30 \mathrm{~s}$ (annealing and elongation), followed by melting temperature analysis from $60-95^{\circ} \mathrm{C}$ (verification of the targeted amplification product). Gene target copies were then calculated as copies per mg of crab muscle, and samples with $>1000$ copies $\mathrm{mg}^{-1}$ were recorded as CsRV1-positive according to Flowers et al. (2016b), which reflects an empirical threshold for field and laboratory cross contamination.

\subsection{Statistical analyses}

We used linear regressions to test relationships between biologically important high and low temperature thresholds and disease prevalence across the sampled range. The correlation between CsRV1 prevalence and high temperature was assessed by a linear regression model of CsRV1 prevalence against $D_{>23}$. The correlation between CsRV1 prevalence and winter dormancy was assessed with a linear regression model of CsRV1 against $D_{<10}$. Both models used the Pearson's product-moment correlation test, and significant correlations were defined as those where $\mathrm{p} \leq 0.05$.

Repeated samples between summer and winter at a subset of temperate locations on the US Atlantic Coast enabled us to examine seasonal drivers of prevalence. To determine whether CsRV1 infection was affected by the categorical factors season or site, binomial (infected vs. non-infected) generalized logistic regression models were used $(\alpha=0.05)$. Akaike's information criterion was used to choose the best fit model (Aho et al. 2014). All statistical tests were conducted using RStudio v.1.1.456 with R v.3.5.1 (R Core Team 2019).

\section{RESULTS}

\subsection{CsRV1 prevalence in different latitudinal locations}

The 776 male and 544 female specimens of Callinectes sapidus ranged from 29.9-196.0 mm CW. Specimens that were PCR-positive for CsRV1 ranged from 41.0-179.0 mm CW. CsRV1 RNA prevalence in C. sapidus $(\mathrm{n}=308)$ sampled from 4 locations on the northeast and mid-Atlantic coast of North America varied from $14.0-32.0 \%$. On the southeast Atlantic coast, CsRV1 prevalence was 1.6 and $0.0 \%$ for Jacksonville and Ormond Beach $(\mathrm{n}=184)$ (Florida, USA), respectively. In the Gulf of Mexico and Caribbean Sea, none of specimens from the Apalachicola Bay (Florida), Mexico, north Dominican Republic, St. Lucia, or Puerto Rico were infected with CsRV1 (n = 189). The other 6 locations in the Gulf of Mexico and Caribbean Sea had specimens positive for CsRV1, with a prevalence ranging from $1.0-5.0 \%(n=491)$. Note that the prevalence of CsRV1 in Texas $(5 \% ; \mathrm{n}=$ $119)$ is the average of the inshore $(0 \% ; \mathrm{n}=77)$ and offshore $(14 \% ; \mathrm{n}=42)$ samples. CsRV1 prevalence ranged from $0-33 \%$ in South America ( $\mathrm{n}=338$ ). Specifically, no CsRV1 infections were identified in 
blue crabs collected from two of the locations in Brazil (Sergipe and Paraná; $n=144$ ), but CsRV1 was detected in Rio Grande do Sul (Brazil) and Uruguay (33.3 and $9.7 \%$, respectively; $\mathrm{n}=194$ ) (Table 1 ).

\subsection{Annual water temperature variation, crab life history, and virus prevalence}

The number of days that the water temperature at each sampling site reached biologically relevant thresholds was correlated with CsRV1 prevalence. As expected, there were fewer $D_{>23}$ in higher latitudes, and an increasing number of days as latitude decreased, with most tropical and subtropical locations having water temperature above $23^{\circ} \mathrm{C}$ throughout the year. In contrast, there were more $D_{<10}$ in temperate locations, which corresponds to longer periods of blue crab winter dormancy at higher latitudes (Table 1). Statistically, CsRV1 prevalence in blue crabs from all tested locations fit a reciprocal linear relationship to $D_{>23}$ (CsRV1 prevalence $[\%]=20.8-0.06 \times D_{>23} ; \mathrm{R}^{2}=0.56, F=$ 26.77, df $=19, \mathrm{p}<0.001$ ) (Fig. 2A); CsRV1 prevalence also fit a strong and positive linear regression model to $D_{<10}$ (CsRV1 prevalence [\%] $=3.0+0.1 \times$ $D_{<10} ; \mathrm{R}^{2}=0.4, F=14.77$, df $=19, \mathrm{p}=0.001$ ) (Fig. 2B), indicating that high temperature and blue crab life history $\left(D_{<10}\right)$ were correlated with CsRV1 prevalence (Fig. 2).

Table 1. Callinectes sapidus reovirus 1 prevalence in blue crabs collected from different geographic locations. Days of water temperature below $10^{\circ} \mathrm{C}\left(D_{<10}\right)$ and above $23^{\circ} \mathrm{C}\left(D_{>23}\right)$ were calculated based on temperatures obtained from nearby NOAA buoys for the USA, Caribbean, and Mexico sampling sites. Brazil temperature data were obtained from Marinha do Brasil, and Uruguay temperature data were based on previous studies (Guerrero et al. 1997, 2010). See Fig. 1 for locations of Map ID

\begin{tabular}{|c|c|c|c|c|c|c|c|c|c|}
\hline Location & $\begin{array}{l}\text { Map } \\
\text { ID }\end{array}$ & $\begin{array}{l}\text { Collection date } \\
\text { (month-year) }\end{array}$ & $\begin{array}{l}\text { Latitude } \\
\qquad\left({ }^{\circ} \mathrm{N}\right)\end{array}$ & $\begin{array}{l}\text { Longitude } \\
\qquad\left({ }^{\circ} \mathrm{W}\right)\end{array}$ & $\begin{array}{c}\text { Total } \\
\mathrm{N}\end{array}$ & $\begin{array}{l}\text { Infected } \\
\mathrm{N}\end{array}$ & $\begin{array}{c}\text { Prevalence } \\
(\%)\end{array}$ & $D_{<10}$ & $D_{>23}$ \\
\hline \multicolumn{10}{|l|}{ Northeast Atlantic } \\
\hline Westport River, MA & 1 & Sep-18 & 41.5118 & 71.0929 & 120 & 20 & 16.7 & 197 & 0 \\
\hline Long Island, NY & 2 & Jul-18 & 40.7738 & 72.8052 & 32 & 10 & 31.2 & 175 & 7 \\
\hline \multicolumn{10}{|l|}{ Mid-Atlantic } \\
\hline Delaware Bay, DE & 3 & Aug-17 & 38.9108 & 75.5277 & 40 & 8 & 20 & 157 & 51 \\
\hline Albemarle Sound, NC & 4 & Oct-19 & 33.8772 & 76.1248 & 116 & 17 & 14.7 & 128 & 135 \\
\hline \multicolumn{9}{|l|}{ Southeast Atlantic } & 193 \\
\hline Ormond Beach, FL & 6 & Dec-17 & 29.2858 & 81.0559 & 60 & 0 & 0 & 11 & 237 \\
\hline \multicolumn{10}{|l|}{ Gulf of Mexico } \\
\hline Cedar Key, FL & 7 & Jan-17 & 29.1236 & 83.0287 & 100 & 1 & 1 & 0 & 273 \\
\hline Apalachicola Bay, FL & 8 & Nov-17 & 29.6718 & 85.0026 & 15 & 0 & 0 & 7 & 237 \\
\hline Port Aransas, TX ${ }^{\mathrm{a}}$ & 9 & $\begin{array}{c}\text { Jun-17, } \\
\text { Nov-18/Mar-19 }\end{array}$ & 27.8006 & 97.3964 & 119 & 6 & 5 & 11 & 193 \\
\hline Florida Keys, FL & 10 & Feb-18 & 24.8234 & 80.8122 & 43 & 1 & 2.1 & 22 & 182 \\
\hline Celestún, Yucatan, Mexico & 11 & Nov-17 & 20.8593 & 90.3972 & 40 & 0 & 0 & 0 & 365 \\
\hline \multicolumn{10}{|l|}{ Caribbean Sea } \\
\hline North Dominican Republic & 12 & Jan-18 & 19.7831 & 71.7507 & 29 & 0 & 0 & 0 & 365 \\
\hline South Dominican Republic & 13 & Jan-18 & 18.4511 & 69.2133 & 40 & 1 & 2.5 & 0 & 365 \\
\hline Canal Suárez, PR & 14 & Jun/Apr-19 & 18.4508 & 65. 9801 & 92 & 0 & 0 & 0 & 365 \\
\hline St Kitts \& Nevis & 15 & $\begin{array}{l}\text { Nov/Dec-18, } \\
\text { Feb/Mar-19 }\end{array}$ & 17.2908 & 62.6773 & 103 & 1 & 1 & 0 & 365 \\
\hline St. Lucia & 16 & Nov-17 & 14.0149 & 60.9920 & 13 & 0 & 0 & 0 & 365 \\
\hline Trinidad \& Tobago & 17 & Mar-17 & 10.4633 & 61.4836 & 86 & 1 & 1.2 & 0 & 365 \\
\hline \multicolumn{10}{|l|}{ South America coast } \\
\hline Sergipe, BR & 18 & Oct-18 & 10.2548 & 36.3208 & 80 & 0 & 0 & 0 & 365 \\
\hline Paraná, BR & 19 & Dec-18 & 25.3340 & 48.4760 & 64 & 0 & 0 & 0 & 210 \\
\hline Rio Grande do Sul, BR & 20 & Jan-15 & 30.0346 & 51.2177 & 39 & 13 & 33.3 & 0 & 114 \\
\hline Uruguay & 21 & Mar-19 & 34.6285 & 54.2921 & 155 & 15 & 9.7 & 0 & 65 \\
\hline
\end{tabular}



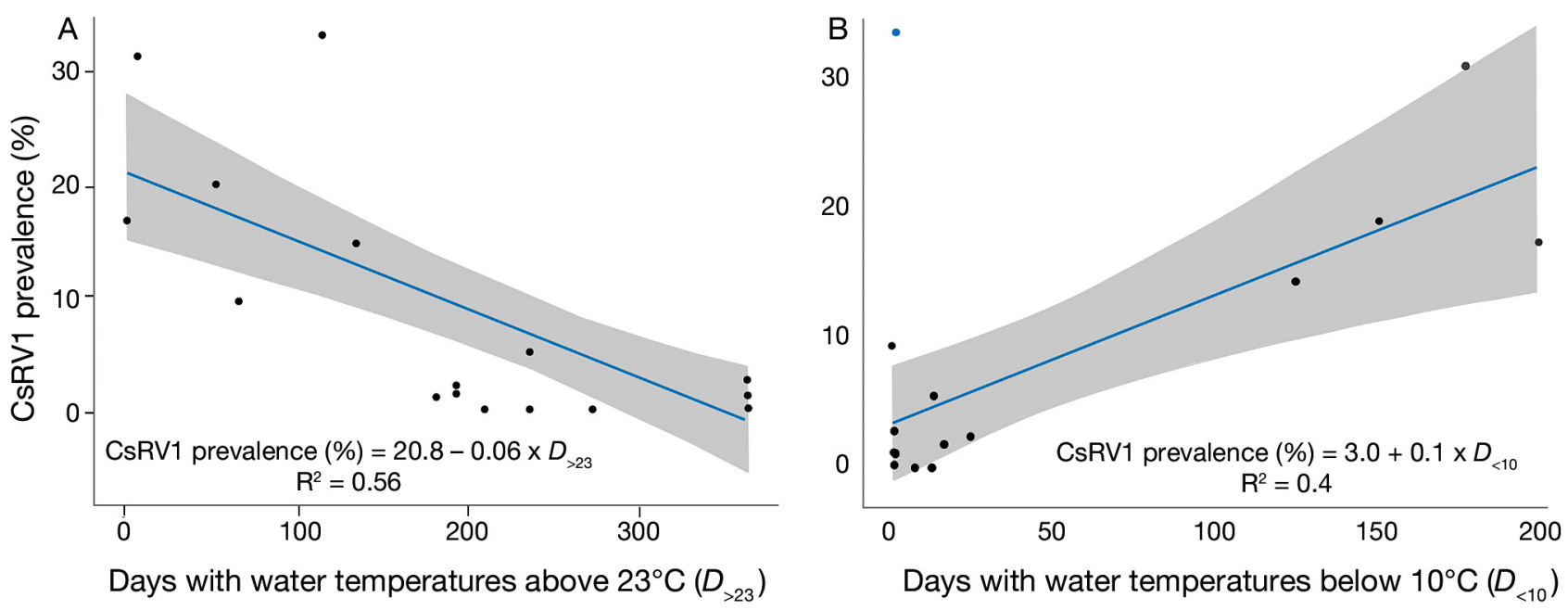

Fig. 2. Prevalence of Callinectes sapidus reovirus 1 (CsRV1) infection versus number of days with water temperatures (A) above $23^{\circ} \mathrm{C}\left(D_{>23}\right)$ and $(\mathrm{B})$ below $10^{\circ} \mathrm{C}\left(D_{<10}\right)$. Blue line: significant $(\mathrm{p}<0.01)$ linear regression; grey shading: $95 \% \mathrm{CI}$. Blue dot in (B) highlights an outlier of the regression model (CsRV1 prevalence in Rio Grande do Sul, BR)

\subsection{CsRV1 prevalence in overwintering $C$. sapidus}

CsRV1 prevalence was low overall in winterdredged crabs (Fig. 3). The average in overwintering crabs $(\mathrm{n}=469)$ collected from 5 locations in the Chesapeake Bay, Potomac River, Delaware Bay, and Albemarle Sound was low, with North Carolina having the highest prevalence at $7.2 \%$ and the Potomac River having the lowest prevalence at $0 \%$. Prevalence in the Upper Chesapeake Bay and Delaware Bay was below 2.0\% and in the Lower Chesapeake Bay was below 5.0\% (Table 2). Prevalence among summer active wild crabs from Delaware Bay and Albemarle Sound was 20.0 and $14.7 \%$, respectively (Table 1). CsRV1 prevalence among active crabs from Chesapeake Bay was based on previous studies (Flowers et al. 2016b, Spitznagel et al. 2019), which found an average of $21.2 \%$ for Upper Chesapeake Bay and 12.5\% for Lower Chesapeake Bay (Fig. 3). The best-fit binomial model predicted CsRV1 prevalence relative to season (slope: $-1.26, \mathrm{p}<0.01$ ). The factor site was not included in the best fit model, suggesting that this pattern was persuasive across 4 sampling sites.

\subsection{CsRV1 in other Callinectes spp.}

No CsRV1 infections were detected in other Callinectes spp. (n = 577), which included 230 C. danae, 13 C. larvatus, 29 C. bocourti, and 3 C. similis. The species were confirmed by clear morphological characteristics or cox1 amplicon sequencing. An additional 302 crabs, determined by 12S rRNA PCR analyses not to be C. sapidus but an unidentified Callinectes spp., all showed no CsRV1 infection (Table 3).

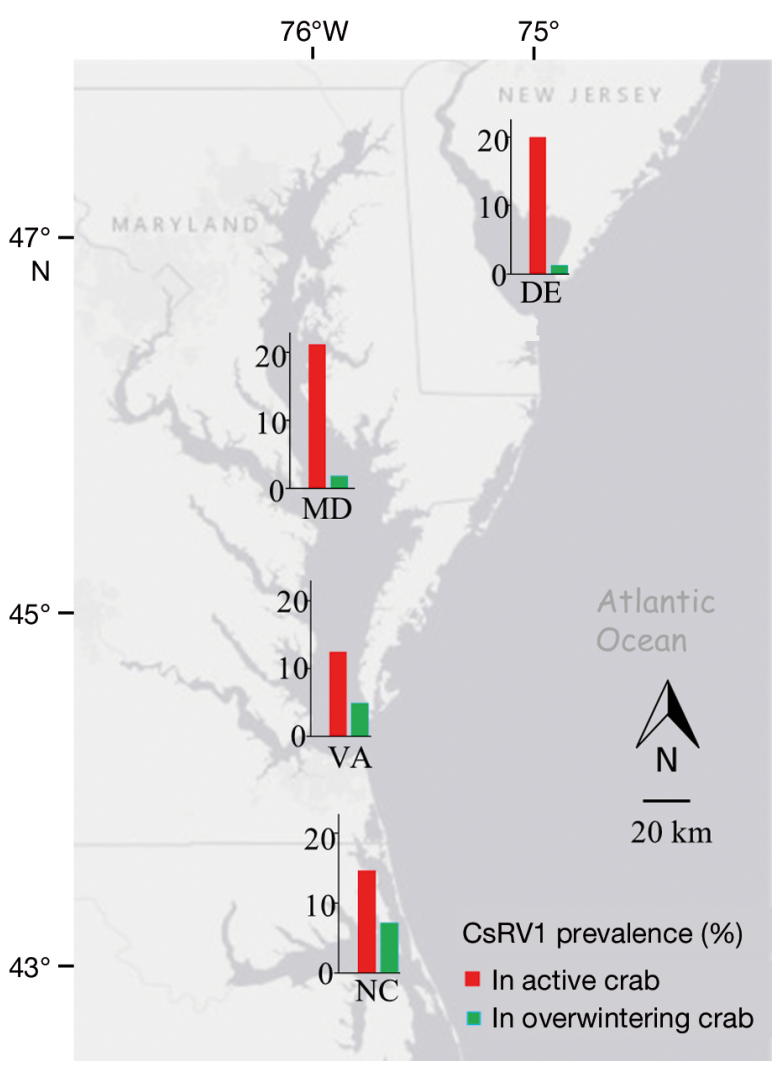

Fig. 3. Prevalence of Callinectes sapidus reovirus 1 (CsRV1) in active versus winter-dormant blue crabs in estuaries of the USA 
Table 2. Callinectes sapidus reovirus 1 prevalence of winter-dredged C. sapidus collected from the mid-Atlantic. Temperature ranges at the time of sampling were obtained from nearby buoy data from the National Buoy Data Center

\begin{tabular}{|lccccc|}
\hline Location & Collection date & Temperature $\left({ }^{\circ} \mathrm{C}\right)$ & Total N & Infected N & Prevalence $(\%)$ \\
\hline Delaware Bay, DE & Mar-19 & 4 to 12 & 75 & 1 & 1.3 \\
Upper Chesapeake Bay, MD & Mar-15 & -1.5 to 6 & 55 & 1 & 1.8 \\
Potomac River, MD & Mar-19 & 5 to 11 & 28 & 0 & 0.0 \\
Lower Chesapeake Bay, VA & Jan/Feb/Mar-18 & 0 to 11 & 102 & 5 & 4.9 \\
Albemarle Sound, NC & Feb-19 & 9 to 14 & 209 & 15 & 7.2 \\
\end{tabular}

Table 3. Other Callinectes spp. (not C. sapidus) tested for Callinectes sapidus reovirus 1 (CsRV1) by quantitative reverse transcription PCR. No CsRV1 infection was detected in these species

\begin{tabular}{|c|c|c|c|c|c|}
\hline Species & Locations & $\begin{array}{l}\text { Number } \\
(\mathrm{N})\end{array}$ & $\begin{array}{c}\text { Total } \\
\mathrm{N}\end{array}$ & $\begin{array}{l}\text { Infected } \\
\mathrm{N}\end{array}$ & $\begin{array}{c}\text { Prevalence } \\
(\%)\end{array}$ \\
\hline C. danae & $\begin{array}{l}\text { St Lucia } \\
\text { Rio Grande do Sul } \\
\text { Paraná } \\
\text { Trinidad \& Tobago }\end{array}$ & $\begin{array}{r}12 \\
15 \\
200 \\
3\end{array}$ & 223 & 0 & 0 \\
\hline C. larvatus & $\begin{array}{l}\text { Florida Keys } \\
\text { St. Lucia }\end{array}$ & $\begin{array}{r}1 \\
12\end{array}$ & 7 & 0 & 0 \\
\hline C. bocourti & $\begin{array}{l}\text { Puerto Rico } \\
\text { Cedar Keys }\end{array}$ & $\begin{array}{r}28 \\
1\end{array}$ & 29 & 0 & 0 \\
\hline C. similis & $\begin{array}{l}\text { Florida Keys } \\
\text { St Lucia }\end{array}$ & $\begin{array}{l}2 \\
1\end{array}$ & 3 & 0 & 0 \\
\hline $\begin{array}{l}\text { Callinectes } \\
\text { spp. }\end{array}$ & $\begin{array}{l}\text { Florida Keys } \\
\text { St Lucia } \\
\text { Grenada } \\
\text { Trinidad \& Tobago } \\
\text { Dominican Republic }\end{array}$ & $\begin{array}{r}4 \\
3 \\
199 \\
11 \\
85\end{array}$ & 315 & 0 & 0 \\
\hline
\end{tabular}

\section{DISCUSSION}

This study revealed that across 2 hemispheres, the prevalence of CsRV1 in Callinectes sapidus was significantly higher in temperate versus subtropical or tropical locations, which correlates with the temperature-driven presence/absence of a host overwintering period. In temperate areas, the prevalence of CsRV1 in overwintering C. sapidus was much lower than in crabs during summer in the same regions. We found no CsRV1 infection in other Callinectes spp. across all tested regions. We discuss how CsRV1 prevalence in C. sapidus could be related to temperature, host life history, or the mortality of infected crabs under stress, and how the host density and apparent host specificity of the virus relates to our understanding of this pathosystem.

\subsection{High temperature}

C. sapidus in the tropics experience higher peak temperatures for longer periods of time relative to crabs in temperate regions. The relationship between CsRV1 prevalence and $D_{>23}$ suggests that higher temperatures in the tropics might result in lower CsRV1 prevalence in blue crabs (Fig. 2A). Water temperature is a key factor influencing both the likelihood and outcome of crustacean disease emergence, by mediating both host physiological and immunological responses to microbial pathogens as well as the responses of the pathogens themselves to different temperatures. It has been reported that Pacific white shrimp Penaeus vannamei are able to clear white spot syndrome virus (WSSV) and have reduced WSSV-related mortality at high temperatures (Rahman et al. 2006, You et al. 2010) through expression of immune-related genes (Lin et al. 2011, Shields 2019). Similarly, in C. sapidus, CsRV1-infected crabs cultured in elevated water temperature have increased immune and metabolism-related gene expression in hemocytes and an elevated proportion of small and non-granulated hemocytes (Chung et al. 2015). Thus, the lower CsRV1 prevalence in higher temperature zones might be a result of an upregulated immune response of the host to combat the virus infection.

Alternatively, in many pathosystems there is an inverse relationship between virulence and prevalence because infections progress more rapidly to mortality. The lower CsRV1 prevalence in the tropics and subtropics could indicate that CsRV1-infected crabs die more quickly than in temperate regions. Preliminary experimental infections of CsRV1 in blue 
crabs showed that virus-infected crabs die more rapidly at $29^{\circ} \mathrm{C}$ than at 16 or $22^{\circ} \mathrm{C}$ (E. J. Schott \& H. A. Bowers unpubl. data). This observation is similar to the Hematodinium perezi-C. sapidus pathosystem, in which a negative relationship was found between high water temperature and the prevalence of $H$. perezi infections in $C$. sapidus megalopae because higher temperature caused faster mortality of infected crabs (Sullivan \& Neigel 2017). We found that the load of CsRV1 RNA was consistently lower in warmer latitudes (Table S3), which could indicate that crabs with higher CsRV1 loads do not live long enough to be sampled. In juvenile C. sapidus infected with $H$. perezi, mortality rises with increasing water temperature (Huchin-Mian et al. 2018) because the transmission and proliferation of the parasite occurs more quickly at warmer temperatures and during extended warm seasons (Shields 2019).

\subsection{Life history}

C. sapidus become dormant at temperatures below $10^{\circ} \mathrm{C}$ (Brylawski \& Miller 2006, Hines et al. 2011), so the correlation between CsRV1 prevalence and $D_{<10}$ suggests that climate-driven life history variation could be associated with CsRV1 prevalence (Fig. 2B). If this relationship is accurate and dormancy drives the prevalence of CsRV1, then seasonal migrations, seasonal mating activity, and stress from entering, enduring, and awakening from dormancy could be mechanisms increasing infection rates at higher latitudes where dormancy occurs. The relationship between low temperature and CsRV1 prevalence did not fit southern Brazil, where crabs appear to experience water that drops to only about $13^{\circ} \mathrm{C}$ in the winter yet the population appears have quite high prevalence (Fig. 2B). Although crabs in this region do not become fully dormant, they do have annual peaks of activity, including peaks of recruitment and reproduction (Rodrigues et al. 2019).

\subsection{Stress and winter dormancy}

Until this study, the only report of CsRV1 in overwintering C. sapidus was that of Messick (1998), who detected $0.3 \%$ prevalence in Chesapeake Bay using histological methods. The present study detected an average dormant-period prevalence of $4.7 \%$ using RT-qPCR methods, which is higher than that reported by Messick (1998), but still much lower than the $20 \%$ RT-qPCR based prevalence found in active
C. sapidus (Fig. 3). A similar difference in $H$. perezi prevalence in active versus dormant C. sapidus has been reported, as has a seasonal increase in prevalence from August-November (Messick 1994, Messick et al. 1999, Shields et al. 2015). The low prevalence of CsRV1 and low copy numbers of virions in dormant $C$. sapidus found to be infected (Table S4) suggests that perhaps winter mortality of infected crabs is high, and only uninfected or lightly infected crabs survive to be sampled. Infected crabs that survive the winter might then serve as a reservoir for CsRV1 when they emerge the following spring. This is similar to what was seen in light and moderate $H$. perezi infections in dredged crabs that respond rapidly to increases in temperature (Shields et al. 2015).

\subsection{Non-linear effects of temperature}

The apparently paradoxical findings - that CsRV1 prevalence was lowest in the warmest areas and in the coldest seasons - reflect the non-linear effects of temperature and the complexity of the factors that contribute to disease progression. In one aspect, it seems that extreme temperatures (high or low) can inhibit either transmission or establishment of CsRV1 infection in C. sapidus and lead to lower prevalence. Similar thermal ranges have been well studied in WSSV-infected shrimps; there is little to no replication of WSSV in shrimps below $13^{\circ} \mathrm{C}$ and above $32^{\circ} \mathrm{C}$ (Shields 2019). This suggests that acclimation of crabs in tropical regions to warmer environmental conditions may make them less susceptible to CsRV1 infection. Alternatively, the decrease in CsRV1 prevalence could also be a signal of increased mortality of infected blue crabs, especially when considering the potential stresses caused by temperature extremes. These opposing hypotheses are both sufficient to explain the empirical observations, but testing them experimentally to show the mechanisms behind the pattern remains to be done.

\subsection{Host density and specificity}

The lower prevalence of CsRV1 at low latitudes could also be related to blue crab population density. The prevalence of infection decreases when the frequency of contact between infected and susceptible hosts is lower than the death or recovery rate of infected hosts (Lafferty 2004). A previous study observed that decreased CsRV1 prevalence in Chesa- 
peake Bay coincided with an interannual decrease in C. sapidus population size (Flowers et al. 2018). Although C. sapidus are distributed along the western Atlantic coast from Nova Scotia (Canada) to northern Argentina (Williams 1974, Arnold 1984), they are less abundant in tropical areas such as the Caribbean Sea and are likely absent from the northeast coast of Brazil (Scarponi et al. 2018). Lower C. sapidus density in the tropics may reduce CsRV1 transmission through reductions in the interactions (mating, conspecific predation) between infected and uninfected hosts. Blue crab habitat in the Caribbean is a discontinuous patchwork of islands, which would further reduce interactions if the pathogen transmits through contact with an infected individual or consumption of infected tissue. One notable weakness with the host-density explanation is that CsRV1 prevalence in the Gulf of Mexico was low yet C. sapidus populations in that region are known to be high (NOAA GSMFC 2015). A prior study of diseases of $C$. sapidus in the Gulf of Mexico also found lower prevalence $(7 \%)$ of CsRV1 than in the mid-Atlantic (Rogers et al. 2015a).

Throughout its tropical and subtropical range, C. sapidus is sympatric with numerous other Callinectes spp. Based on morphology, and confirmed by DNA barcoding, all of the crabs collected from the Atlantic coast of the USA and Uruguay were C. sapidus, while many of the collections from the Caribbean and Gulf of Mexico included C. danae, C. larvatus, C. bocourti, and C. similis (Table 3). Of the other Callinectes spp. tested $(\mathrm{n}=577)$, none were infected with CsRV1, which indicates CsRV1 is likely to be host-specific to C. sapidus. This further supports the hypothesis that outside of temperate areas, CsRV1 prevalence in $C$. sapidus might be limited by lower host population density. Nevertheless, other reservoir hosts are possible and should be investigated.

\subsection{Concluding remarks and next steps}

To better understand the various influences on this complex pathosystem, it is necessary to combine field observations with experimental data as suggested by Sullivan \& Neigel (2017). Laboratory experiments are needed to test the effect of temperature on the progression of CsRV1 infections and resulting mortality rates across a wide temperature gradient representing temperate to tropical environments. Additionally, the effects of crab size on CsRV1 infection warrant further study. Many crabs were collected by fisherydependent methods (e.g. trap, trawl, and dredge) and were above minimum landing size, so we are reluctant to draw specific connections between CsRV1 prevalence and crab size or sex in this study. Environmental variation and host life history may combine to drive the evolution of CsRV1 virulence. Sequence analyses of the CsRV1 RNA-dependent RNA polymerase gene (Flowers et al. 2016a) and whole genome sequences of CsRV1 (M. Zhao unpubl. data) indicate that there are different genotypes of CsRV1 at different latitudes. If differential mortality rates are caused by regionally specific genotypes of CsRV1 strains, it may help to explain geographic variation of CsRV1 prevalence.

This study suggests that CsRV1 prevalence could be affected by temperature, season, and crab life history across both hemispheres, and provides the foundation for developing testable hypotheses to determine how environmental stress, seasonality, population density, and virus genetics might combine to produce the observed prevalence of CsRV1. A better understanding of environment-host-pathogen interactions across climatic gradients also gives us foresight into what we might expect under future climate scenarios.

Acknowledgements. This work was supported by NSF Division of Ocean Sciences-Biological Oceanography awards 1658466 (E.J.S., L.P.) and 1658396 (D.B.). M.Z. was supported by an award from the China Scholarship Council. We thank our collaborators and the many fishermen for assistance in collecting and processing samples, especially Zachary Darnell (University of Southern Mississippi) and Marcelo Chammas (Aquatrix Consultoria e Projetos Ltda, Sergipe, BR). We are very grateful to Colleen Burge (University of Maryland, Baltimore County Institute of Marine Environmental Technology) for reviewing the manuscript and for the thoughtful feedback from peer reviewers. We also thank Olivia Pares (University of Maryland Center for Environmental Science [UMCES] Institute of Marine Environmental Technology) for the expert assistance with map creation and Matthew Spitznagel (UMCES Institute of Marine Environmental Technology) for his help with RT-qPCR methodology.

\section{LITERATURE CITED}

Adkins G (1972) A study of the blue crab fishery in Louisiana. Technical Bulletin No. 3. Louisiana Wildlife and Fisheries Commission, Baton Rouge, LA

Aho K, Derryberry D, Peterson T (2014) Model selection for ecologists: the worldviews of AIC and BIC. Ecology 95: 631-636

Arnold WS (1984) The effects of prey size, predator size, and sediment composition on the rate of predation of the blue crab, Callinectes sapidus Rathbun, on the hard clam, Mercenaria mercenaria (Linné). J Exp Mar Biol Ecol 80: 207-219 
Behringer DC, Karvonen A, Bojko J (2018) Parasite avoidance behaviours in aquatic environments. Philos Trans $\mathrm{R}$ Soc B 373:20170202

*Bowers HA, Messick GA, Hanif A, Jagus R, Carrion L, Zmora O, Schott EJ (2010) Physicochemical properties of double-stranded RNA used to discover a reo-like virus from blue crab Callinectes sapidus. Dis Aquat Org 93: $17-29$

Brady OJ, Golding N, Pigott DM, Kraemer MU and others (2014) Global temperature constraints on Aedes aegypti and Ae. albopictus persistence and competence for dengue virus transmission. Parasit Vectors 7:338

Brylawski B, Miller T (2006) Temperature-dependent growth of the blue crab (Callinectes sapidus): a molt process approach. Can J Fish Aquat Sci 63:1298-1308

Chung JS, Pitula JS, Schott E, Alvarez JV, Maurer L, Lycett KA (2015) Elevated water temperature increases the levels of reo-like virus and selected innate immunity genes in hemocytes and hepatopancreas of adult female blue crab, Callinectes sapidus. Fish Shellfish Immunol 47: 511-520

* Engering A, Hogerwerf L, Slingenbergh J (2013) Pathogen-host-environment interplay and disease emergence. Emerg Microbes Infect 2:e5

Flowers EM, Bachvaroff TR, Warg JV, Neill JD and others (2016a) genome sequence analysis of CsRV1: a pathogenic reovirus that infects the blue crab Callinectes sapidus across its trans-hemispheric range. Front Microbiol 7:126

Flowers EM, Simmonds K, Messick GA, Sullivan L, Schott EJ (2016b) PCR-based prevalence of a fatal reovirus of the blue crab, Callinectes sapidus (Rathbun) along the northern Atlantic coast of the USA. J Fish Dis 39:705-714

Flowers EM, Johnson AF, Aguilar R, Schott EJ (2018) Prevalence of the pathogenic crustacean virus Callinectes sapidus reovirus 1 near flow-through blue crab aquaculture in Chesapeake Bay, USA. Dis Aquat Org 129: 135-144

Ford S, Chintala M (2006) Northward expansion of a marine parasite: testing the role of temperature adaptation. J Exp Mar Biol Ecol 339:226-235

Franke F, Armitage SAO, Kutzer MAM, Kurtz J, Scharsack JP (2017) Environmental temperature variation influences fitness trade-offs and tolerance in a fish-tapeworm association. Parasit Vectors 10:252

Goodwin AE, Merry GE (2011) Replication and persistence of VHSV IVb in freshwater turtles. Dis Aquat Org 94: 173-177

Guerrero RA, Acha EM, Framiñan MB, Lasta CA (1997) Physical oceanography of the Río de la Plata Estuary, Argentina. Cont Shelf Res 17:727-742

Guerrero RA, Piola AR, Molinari GN, Osiroff AP, Jáuregui SI (2010) Climatología de temperatura y salinidad en el Río de la Plata y su Frente Marítimo. Argentina-Uruguay. Instituto Nacional de Investigación y Desarrollo Pesquero, Mar del Plata

Hardy JL, Houk EJ, Kramer LD, Reeves WC (1983) Intrinsic factors affecting vector competence of mosquitoes for arboviruses. Annu Rev Entomol 28:229-262

* Hawley LM, Garver KA (2008) Stability of viral hemorrhagic septicemia virus (VHSV) in freshwater and seawater at various temperatures. Dis Aquat Org 82:171-178

Hines AH (2003) Ecology of juvenile and adult blue crabs: summary of discussion of research themes and directions. Bull Mar Sci 72:423-433
Hines AH (2007) Ecology of juvenile and adult blue crabs. In: Kennedy VS, Cronin LE (eds) Biology of the blue crab. Maryland Sea Grant College Program, College Park, MD, p 565-654

Hines AH, Johnson E, Darnell M, Rittschof D and others (2011) Predicting effects of climate change on blue crabs in Chesapeake Bay. In: Kruse GH, Eckert GL, For RJ, Lipcius RN, Sainte-Marie B, Stram DL, Woodby D (eds) Biology and management of exploited crab populations under climate change. Alaska Sea Grant College Program, Fairbanks, AK, p 109-127

*Hoberg EP, Brooks DR (2015) Evolution in action: climate change, biodiversity dynamics and emerging infectious disease. Philos Trans R Soc B 370:20130553

*Hsueh PW, McClintock JB, Hopkins TS (1993) Population dynamics and life history characteristics of the blue crabs Callinectes similis and C. sapidus in bay environments of the northern Gulf of Mexico. Mar Ecol 14:239-257

*Huchin-Mian JP, Small HJ, Shields JD (2018) The influence of temperature and salinity on mortality of recently recruited blue crabs, Callinectes sapidus, naturally infected with Hematodinium perezi (Dinoflagellata). J Invertebr Pathol 152:8-16

Johnson PT (1977) A viral disease of the blue crab, Callinectes sapidus: histopathology and differential diagnosis. J lnvertebr Pathol 29:201-209

* Labaude S, Moret Y, Cezilly F, Reuland C, Rigaud T (2017) Variation in the immune state of Gammarus pulex (Crustacea, Amphipoda) according to temperature: Are extreme temperatures a stress? Dev Comp Immunol 76: 25-33

Lafferty KD (2004) Fishing for lobsters indirectly increases epidemics in sea urchins. Ecol Appl 14:1566-1573

* Leray M, Knowlton N (2015) DNA barcoding and metabarcoding of standardized samples reveal patterns of marine benthic diversity. Proc Natl Acad Sci USA 112: 2076-2081

K Lin YR, Hung HC, Leu JH, Wang HC, Kou GH, Lo CF (2011) The role of aldehyde dehydrogenase and hsp70 in suppression of white spot syndrome virus replication at high temperature. J Virol 85:3517-3525

Lipcius R (1986) Variable functional responses of a marine predator in dissimilar homogeneous microhabitats. Ecology 67:1361-1371

Melo GAS (1996) Manual de identificação dos Brachyura (caranguejos e siris) do litoral brasileiro. FAPESP, São Paulo

Messick GA (1994) Hematodinium perezi infections in adult and juvenile blue crabs Callinectes sapidus from coastal bays of Maryland and Virginia, USA. Dis Aquat Org 19: 77-82

Messick GA (1998) Diseases, parasites, and symbionts of blue crabs (Callinectes sapidus) dredged from Chesapeake Bay. J Crustac Biol 18:533-548

* Messick GA, Shields JD (2000) Epizootiology of the parasitic dinoflagellate Hematodinium sp. in the American blue crab Callinectes sapidus. Dis Aquat Org 43:139-152

Messick GA, Jordan SJ, Heukelem WF (1999) Salinity and temperature effects on Hematodinium sp. in the blue crab Callinectes sapidus. J Shellfish Res 18:657-662

National Marine Fisheries Service (2020) Commercial fisheries statistics https://foss.nmfs.noaa.gov/apexfoss/ (accessed 18 March 2020)

NOAA GSMFC (Gulf States Marine Fisheries Commission) (2015) The blue crab fishery of the Gulf of Mexico, 
United States: a regional management plan. www.gsmfc. org/publications/GSMFC\%20Number\%20243_web.pdf (accessed 18 March 2020)

R Core Team (2019) R: a language and environment for statistical computing. R Foundation for Statistical Computing, Vienna

Rahman M, Escobedo-Bonilla C, Corteel M, Lima J and others (2006) Effect of high water temperature $\left(33^{\circ} \mathrm{C}\right)$ on the clinical and virological outcome of experimental infections with white spot syndrome virus (WSSV) in specific pathogen-free (SPF) Litopenaeus vannamei. Aquaculture 261:842-849

Rodrigues MA, Ortega I, D'Incao F (2019) The importance of shallow areas as nursery grounds for the recruitment of blue crab (Callinectes sapidus) juveniles in subtropical estuaries of Southern Brazil. Reg Stud Mar Sci 25:100492

Rodríguez-Ezpeleta N, Teijeiro S, Forget L, Burger G, Lang BF (2009) Construction of cDNA libraries: focus on protists and fungi. Methods Mol Biol 533:33-47

Rogers HA, Taylor SS, Hawke JP, Anderson Lively JA (2015a) Variations in prevalence of viral, bacterial, and rhizocephalan diseases and parasites of the blue crab (Callinectes sapidus). J Invertebr Pathol 127:54-62

Rogers HA, Taylor SS, Hawke JP, Schott EJ, Anderson Lively JA (2015b) Disease, parasite, and commensal prevalences for blue crab Callinectes sapidus at shedding facilities in Louisiana, USA. Dis Aquat Org 112:207-217

Samuel GH, Adelman ZN, Myles KM (2016) Temperaturedependent effects on the replication and transmission of arthropod-borne viruses in their insect hosts. Curr Opin Insect Sci 16:108-113

Scarponi P, Coro G, Pagano P (2018) A collection of Aqua-

Editorial responsibility: Toshi Nagata,

Kashiwanoha, Japan maps native layers in NetCDF format. Data Brief 17: 292-296

Shields JD (2019) Climate change enhances disease processes in crustaceans: case studies in lobsters, crabs, and shrimps. J Crustac Biol 39:673-683

Shields JD, Sullivan SE, Small HJ (2015) Overwintering of the parasitic dinoflagellate Hematodinium perezi in dredged blue crabs (Callinectes sapidus) from Wachapreague Creek, Virginia. J Invertebr Pathol 130:124-132

Small HJ, Huchin-Mian JP, Reece KS, Pagenkopp Lohan KM, Butler MJ IV, Shields JD (2019) Parasitic dinoflagellate Hematodinium perezi prevalence in larval and juvenile blue crabs Callinectes sapidus from coastal bays of Virginia. Dis Aquat Org 134:215-222

* Spitznagel M, Small HJ, Lively JA, Shields JD, Schott EJ (2019) Investigating risk factors for mortality and reovirus infection in aquaculture production of soft-shell blue crabs (Callinectes sapidus). Aquaculture 502: 289-295

Sullivan TJ, Neigel JE (2017) Differential host mortality explains the effect of high temperature on the prevalence of a marine pathogen. PLOS ONE 12:e0187128

Williams BA (1974) The swimming crab of the genus Callinectes (Decapoda, Portunidae). Fish Bull 72:685-798

Williams BA (2007) Systematics and evolution. In: Kennedy VS, Cronin LE (eds) The blue crab: Callinectes sapidus. Maryland Sea Grant, College Park, MD, p 1-16

You XX, Su YQ, Mao Y, Liu M, Wang J, Zhang M, Wu C (2010) Effect of high water temperature on mortality, immune response and viral replication of WSSV-infected Marsupenaeus japonicus juveniles and adults. Aquaculture 305:133-137

Submitted: March 19, 2020; Accepted: June 29, 2020

Proofs received from author(s): August 6, 2020 